\title{
ROLE OF PANCHATIKTA KSHEERGHRITA BASTI IN THE MANAGEMENT OF SANDHIGATA VATA WITH SPECIAL TO OSTEOARTHRITIS: A CASE STUDY
}

\section{Kalpana Pandurang Rathod ${ }^{* 1}$, Pathrikar Anaya ${ }^{2}$, Paradkar Hemant ${ }^{3}$}

1. P.G. Scholar,

2. Guide, Professor and HOD,

3. Associate Professor

Department of Kaychikitsa, APM'S Ayurved Mahavidyalaya Sion, Mumbai- 22

*Corresponding author: E-mail: kalpanarathod2912@gmail.com;no:7767933774

\begin{abstract}
:
symptomatically good result in Sandhigat

Ageing is a process of physical, Vata.

psychological and social change in multi dimensional aspect. Geriatric health care is very important. Sandhigata Vata i.e. osteoarthritis is also known as degenerative joint disease. Majority of geriatric population suffer from Sandhigata Vata. Modern medicine has limitation in treating Osteoarthritis and has many adverse effects with its prolonged use. Now in the era of TKR (Total Knee Joint Replacement) Surgery, but due to some underlying systemic illness, financial constrains it is not possible to opt for surgical intervention.. In Ayurveda it is mentioned that in Vardhakya Avastha all Dhatus undergo Kshay leading to Dhatukshayaj Vatprakopa Samprapti. In Sandhigata Vata there is Kshay of Asthidhatu. Bastichikitsa is considered to be Shreshtha(best) in Vata dosha Chikitsa. In the present case Panchatikta Ksheerbasti along with sarpi (Ghee)was given in the patient suffering from $\mathrm{OA}$ for 30days. Panchatikta Ksheerbasti showed

Keywords; Vatavyadhi, Sandhigata Vata, Panchatikta Ksheerghrita Basti.

\section{Introduction:}

- Vatavyadhis are divided into two type Upstambhit and Nirupstambhit. The major aetiological factors of Sandhigata Vata are Vegasandharan, Ativyayam, Ratrojagran, Abhighata etc.

- Sandhigata Vata can be correlated with Osteoarthritis mentioned in modern medicine. It is degenerative joint disease in which there is degeneration of joint, articular cartilages and subchondral bone. It is caused by mechanical stress to joints produces symptoms like joint pain, swelling, stiffness.

- The incidence of Osteoarthritis in India is as high as $12 \%$, it is
\end{abstract}


estimated approximately four out of 100 people are affected by it. Osteoarthritis is most common articular disorder beings asymptomatically in the $2^{\text {nd }}$ and $3^{\text {rd }}$ decades and is extremely common by age 70 . Almost all persons by age 40 have some pathological changes in weight bearing joint, $25 \%$ females and $16 \%$ males have symptoms of Osteoarthritis.

- Allopathic treatment has its own limitation in managing this disease. It has either conservative or surgical treatment modalities and is highly symptomatic. There are also some side effects. Such type of condition can be very well managed by the medicines and procedure in ayurvedic texts.

- Charakacharya described panchatikta Dravyas and panchatikta ksheerghrita in Asthyashrit Vyadhi. He had also mentioned the importance of sthanic snehana, swedana and basti in vatdosha upkramass.

- This Case Report consists of study of Sandhigata Vata wherein Panchatikta Ksheerghrita Basti was administered for 30 days.

\section{Case Report:}

A 50 yr old male patient came with complaints of Both Knee joint pain, Restricted movements of both Knee joint Difficulty to walk since 5 months also Kshudhamandya, since 15 days.

Patient had taken allopathic treatment before coming to hospital. Patient was throughly examined and detailed history was taken. Patient was farmer by occupation; patient did not have history of any major illness.
On examination:

General condition- moderate, afebrile,

PR-80/min, regular, no pallor

Local examination of knee joint patient was having-

\begin{tabular}{|c|c|c|}
\hline $\begin{array}{l}\text { Sign } \\
\text { symptoms }\end{array}$ & $\begin{array}{l}\text { Right } \\
\text { Knee }\end{array}$ & $\begin{array}{l}\text { Left } \\
\text { Knee }\end{array}$ \\
\hline Crepitus & Present & Present \\
\hline Swelling & Present & Absent \\
\hline Stiffness & Present & Present \\
\hline $\begin{array}{ll}\text { Flexion } & \text { and } \\
\text { extension } & \end{array}$ & Painful & Painful \\
\hline
\end{tabular}

Routine investigation such as CBC, RBS, Urine Routine, Microscopic were in normal range.

RA test, Uric acid was in normal limits.

X-ray of bilateral knee joint Anteroposterior and Lateral view -

Impression- Intra-articular space reduction and presence of osteophytes. Early degerative changes in both knee joints.

As per Ayurvedic texts the symptoms of Sandhigata Vata are: Vatapurna Druti SprashShotha Sandhigate Anile Prasaran Aakuchanyoho Pravrutti Savedana.

\section{Diagnosis: Sandhigatavata(janu)}

\section{Treatment given:}

As Sandhigat Vatavyadhi is one of the type of Vatavyadhi so line of treatment is Snehana, Swedana and Bastichikitsa.

\section{PURVA KARMA:}

- Sarvanga snehan,swedan

- Preparation of basti 
The treatment was planned as below:

Panchatikta Ksheerghrit Basti for 30 days

Preparation of Panchatikta

\section{Ksheerghrita Basti :}

130ml Decoction (kwatha) of panchatikta Dravyas i.e.Guduchi, Nimba. Vasa, Patol. Kantakari this five drug were used. In panchatikta ksheer basti. All dravyas are Tikta rasa and Vatshaman karya.

$130 \mathrm{ml}$ of Godugdha was added and the Siddha Ksheer was prepared.

Mixing of Basti:

Madhu(5ml) + Goghrita $(20 \mathrm{ml})$

+Siddhakseer (130ml).

Total $150 \mathrm{ml}$ of panchatikta ksheerghrita basti was given daily for 30 days.

\section{PRADHAN KARMA}

\section{Basti Schedule: 30 days}

Total $150 \mathrm{ml}$ of panchatikta ksheerghrita basti was given daily for 30 days.

\section{Pashchat Karma:}

Subjects were asked to sleep in supine position for $10 \mathrm{~min}$.

Parihara kala for 60 days.

* Samyak laxanas were assessed daily after the administration of Basti.

* The results were assessed on the basis of Signs and symptoms of sandhigata vata before and

after treatment.And bastipratyagaman kala was noted. Bastipratyagaman kala was found to be 5 to $7 \mathrm{hrs}$.

Assessment Criteria: Bilateral Knee joint pain:

\begin{tabular}{|l|l|}
\hline Mild & 1 \\
\hline Moderate & 2 \\
\hline Severe & 3 \\
\hline
\end{tabular}

Movement of bilateral Knee joint:

\begin{tabular}{|l|l|}
\hline Free & 0 \\
\hline Mildly restricted & 1 \\
\hline Moderately restricted & 2 \\
\hline Severely restricted & 3 \\
\hline
\end{tabular}

Distance walked by patient within 15 minutes:

\begin{tabular}{|l|l|}
\hline 90 feet & 0 \\
\hline 60 feet & 1 \\
\hline 30 feet & 2 \\
\hline Less than 30 feet & 3 \\
\hline
\end{tabular}

Obeservation in present case:

\begin{tabular}{|l|l|l|l|}
\hline $\begin{array}{l}\text { Sign and } \\
\text { symptoms }\end{array}$ & $\begin{array}{l}\text { Before } \\
\text { treatment }\end{array}$ & $\begin{array}{l}\text { After } \\
\text { treatment }\end{array}$ & Relief \\
\hline $\begin{array}{l}\text { Bilateral joint } \\
\text { knee } \\
\text { pain }\end{array}$ & 3 & 1 & $76 \%$ \\
\hline $\begin{array}{l}\text { Movement of } \\
\text { knee joint }\end{array}$ & 2 & 0 & $76 \%$ \\
\hline $\begin{array}{l}\text { Distance } \\
\text { walked by } \\
\text { patient } \\
\text { within } \\
\text { minutes } 15\end{array}$ & 2 & 0 & $76 \%$ \\
\hline
\end{tabular}

\section{Result And Discussion :}

In above case study patient got $76 \%$ relief in above symptoms of Sandhigata Vata. Above case was of Sandhigata Vatavyadhi and is type of Nirupstambhit Vatvyadhi. In which Asthidhatu Kshay was present. As 
the vitiated Doshaj circulate in the body and where they found the "Kha-vaigunya" i.e. Sandhi, they lodged there to produce the disease. This result into symptomVatpurnadrutisparsh,

Shotha,Prasaransankochanyo Pravrutti Savedana. It seems to be similar with Osteoarthritis.

Mode of action:

The factors influencing the disease were Mandagni, vitiated Vatadosha, Apatarpana and, so line of treatment was Basti, Snehana Swedana, Vedanashaman.

\section{Samprapti :}

Hetusevan+ Asthi Dhatukshay

Vatadosh Dushti, Vataprakopa

Sandhipradeshi Sthansanshray

Sandhigatavatvyadhi

\section{Samprapti Vighatana:}

In Asthivaha Strotodushti Chikitsa Panchatikta Dravya Siddha Ksheer Basti and Sarpi are mentioned and are Rasayana for Asthi Dhatu. They rejuvenate the Dhatus, repair them, remove Kha Vaigunya, give Bala (strength) to the
Dhatu, maintain their healthy condition and restricts/ show down the progress of disease.

\section{Conclusion:}

The treatment given for Sandhigata Vata was Snehana, Swedana, and Basti which helped in Vatadosha Shaman, relief in symptoms of disease and also an attempt to provide safe and effective treatment to the patient.

\section{Reference:}

1. Dr. Bramhananda Tripathi, Charaksamhita, 2009- edition, Chaukhamba Surbharati Publication, Varanasi

2. Sushruta Samhita. Acharya Trikamji, Chaukambha Orientalia, $8^{\text {th }}$ edition 2005, Varanasi

3. Clinical Orthopaedic Diagnosis :Sureshwar Pandey and Anil Kumar Pandey $3^{\text {rd }}$ edition.

4. Braun J.Inception cohort for orthopathies (pub Med)

5. Essential orthopaedies :J.Maheshwary ( $3^{\text {rd }}$ edition 2004)

6. Hamilton Baily's Physical Signs: S.P. Lumley (18 ${ }^{\text {th }}$ edition, 2001)

Cite article:

ROLE OF PANCHATIKTA KSHEERGHRITA BASTI IN THE MANAGEMENT OF SANDHIGATA VATA WITH SPECIAL TO OSTEOARTHRITIS: A CASE STUDY Kalpana Pandurang Rathod, Pathrikar Anaya, Paradkar Hemant Ayurlog: National Journal of Research in Ayurved Science- 2018; (6)(6): 1-4 